\title{
GDP vs genuine progress quantification of economic performance in South Korea and Malaysia
}

\author{
Mastura Hashim • Imtiaz Mohammad Sifat • Azhar Mohamad ${ }^{*}$ \\ Department of Finance, International Islamic University Malaysia, Kuala Lumpur, Malaysia
}

Received: 30 May 2018

Revised: 30 October 2018

Accepted: 5 November 2018

\begin{abstract}
Malaysia and South Korea, successful graduates of Asian Financial Crisis, employed different paths to recovery via Capital Control and IMF bail-out respectively. This paper tracks recovery trajectories of the two nations via orthodox and emergent growth indicators: GDP and GPI. We report unemployment, open-trade, fixed capital accumulation, and prior crisis to be influential determinants of both metrics, while credit and foreign exchange rate lack significance.
\end{abstract}

Keywords: GDP; genuine progress; sustainable growth; Malaysia; South Korea JEL Classification Codes: O44, Q01, Q56, R11

\section{Premise}

The 1997 Asian Financial Crisis serves as a pivotal point for measuring economic performances of most of its crisis-struck constituents. Within this literature, of particular import are Malaysia and South Korea-having applied dissimilar antidotes. The former adopted independent (capital controls) recovery plans, while Korea adopted the IMF treatment. Post-crisis, both nations are regarded as success stories, having achieved rapid growth, despite taking different routes, as measured by medium-term rates of GDP growth within a decade (Zumkehr \& Andriesse, 2008).

The traditional yardstick of quantifying economic growth, GDP - along with its various derivatives like GNP and GNI, faces competition today from a number of alternative metrics. Economists and development experts of various disciplines, ranging as far back as $1960 \mathrm{~s}$, objected to multiple limitations of GDP as an economic performance measure. Most notably, sustainability advocates underscore GDP's shortfalls as a general metric for well-being. These concerns have led to the experimentation and development of an eclectic array of indices for policy legislation from the 1970s onwards. Among them, Genuine Progress Indicator (GPI) has been demonstrating a rise in prominence as an alternative performance measure, particularly

\footnotetext{
* Corresponding author. E-mail: m.azhar@iium.edu.my.

Citation: Hashim, M., Sifat, I. M., and Mohamad, H. (2018) GDP vs genuine progress quantification of economic performance in South Korea and Malaysia, Economics and Business Letters, 7(4), 169-179.
} 
through reproduction at various regional and national levels as listed in Posner \& Costanza (2011) and Bleys \& Whitby (2015). Despite growing interest, quantification and adoption of GPI is very much in its infancy. Moreover, GPI figures are uncalculated for a great portion of world economies. For Malaysia and South Korea in particular, there are calls from academia and policy levels for development of GPI indices (Othman et al., 2014; Feeny et al., 2013).

GPI is best defined in its general framework based on the work of Talberth et al. (2007). As the metric's parametrization is still a "work in progress," a consensus on GPI's definition is yet not reached. As such, countries applying the GPI measure broadly rely on the precedents set by other bodies and calibrate to suit its unique environment. Hence, a component of GPI for a country might not be the component for another country. Empirical attempts till date mostly use the same personal consumption data as GDP but make additions to account for the services from consumer durables, public infrastructure, volunteering, housework values, deductions to account for income inequality and costs of crime, environmental degradation, and loss of leisure. Its advocates claim that by incorporating the forestated variables this indicator better reflects sustainability performances of an economy.

\section{Study design}

The study utilizes secondary data, mainly sourced from the World Bank, from 1980 to 2014, for all determinants except for GPI and external debt. A summary of the sources for data (except for GPI) is provided in Table 1.

Table 1. Summary of Data Sources (I).

\begin{tabular}{|c|c|c|c|c|c|}
\hline Code & Variable & Source & Details & Freq & $\begin{array}{l}\text { Period } \\
\text { available }\end{array}$ \\
\hline GDP & $\begin{array}{l}\text { Gross } \\
\text { Domestic } \\
\text { Product }\end{array}$ & World Bank & GDP at purchaser's prices (current US\$). & Annual & $1980-2014$ \\
\hline DEBT & External Debt & $\begin{array}{l}\text { Collins and } \\
\text { Park (1989), } \\
\text { OECD External } \\
\text { Debt Statistics } \\
\text { (EDS; various } \\
\text { editions), } \\
\text { Sheng (2009), } \\
\text { Bank of Korea, } \\
\text { World Bank }\end{array}$ & $\begin{array}{l}\text { All data are in current U.S. dollars. Data for } \\
\text { Malaysian external debt are from the World } \\
\text { Bank website, as for South Korea there are } \\
\text { limitations due to obtaining from a single } \\
\text { source, thus, this study employs combination of } \\
\text { sources. }\end{array}$ & Annual & $1980-2014$ \\
\hline OPEN & $\begin{array}{l}\text { Trade } \\
\text { Openness }\end{array}$ & World Bank & $\begin{array}{l}\text { Ratio of the value of trade (value of imports } \\
\text { plus value of exports) to GDP. }\end{array}$ & Annual & $1980-2014$ \\
\hline FC & Fixed Capital & World Bank & $\begin{array}{l}\text { Includes land improvements - such as } \\
\text { boundary markers, channels, drains, etc. - } \\
\text { purchase of plant, machinery, and equipment, } \\
\text { and the construction of roads, railways, together } \\
\text { with schools, offices, hospitals, private } \\
\text { residential dwellings, and commercial and } \\
\text { industrial builds. All data are in current U.S. } \\
\text { dollars. }\end{array}$ & Annual & $1980-2014$ \\
\hline UNEMP & $\begin{array}{l}\text { Unmployment } \\
\text { Rate }\end{array}$ & $\begin{array}{l}\text { IMF IFS and } \\
\text { DOS Malaysia }\end{array}$ & $\begin{array}{l}\text { For the years that are unavailable, data are } \\
\text { interpolated. }\end{array}$ & Annual & $\begin{array}{l}\text { KOR: 1980- } \\
\text { 2014; MYS: } \\
\text { 1982-2014 }\end{array}$ \\
\hline INF & Inflation & World Bank & $\begin{array}{l}\text { Measured by the consumer price index in the } \\
\text { current U.S. dollar. }\end{array}$ & Annual & $1980-2014$ \\
\hline CREDIT & $\begin{array}{l}\text { Domestic } \\
\text { Credit } \\
\text { provided by } \\
\text { the financial } \\
\text { sector }\end{array}$ & World Bank & $\begin{array}{l}\text { Includes all gross claims to various segments } \\
\text { except to the central government, which is in } \\
\text { net amount, derived as percentage of GDP. }\end{array}$ & Annual & $1980-2014$ \\
\hline
\end{tabular}




\begin{tabular}{|c|c|c|c|c|c|}
\hline FDI & $\begin{array}{l}\text { Foreign } \\
\text { Direct } \\
\text { Investment }\end{array}$ & World Bank & $\begin{array}{l}\text { Net inflows of foreign direct investment are } \\
\text { used to represent financial openness. All data } \\
\text { are in current U.S. dollars. }\end{array}$ & Annual & 1980-2014 \\
\hline EXC & $\begin{array}{l}\text { Exchange } \\
\text { Rate }\end{array}$ & World Bank & $\begin{array}{l}\text { The exchange rate established by national } \\
\text { authorities and defined as the price of one } \\
\text { currency in terms of another. }\end{array}$ & Annual & 1980-2015 \\
\hline I & Interest Rate & World Bank & $\begin{array}{l}\text { Deposit interest rate is used to represent many } \\
\text { interest rates coexisting in an economy and } \\
\text { these rates differ by country. }\end{array}$ & Annual & 1980-2014 \\
\hline CRID & $\begin{array}{l}\text { Financial } \\
\text { Crisis } \\
\text { Dummy }\end{array}$ & & $\begin{array}{l}\text { Follow Reinhart \& Rogoff, (2011; 2014), and } \\
\text { Tamirisa et al. (2007) to represent the } 1997 \\
\text { Asian financial crisis. " } 1 \text { " is assigned to the } \\
\text { years of crisis and " } 0 \text { " is assigned to the years } \\
\text { without crisis. }\end{array}$ & Annual & 1980-2014 \\
\hline COND & $\begin{array}{l}\text { Capital } \\
\text { Control } \\
\text { Dummy }\end{array}$ & & $\begin{array}{l}\text { Follow Doraisami (2004) and Inoguchi (2009). } \\
\text { "1" is for Malaysia (implemented control) and } \\
\text { "0" is for South Korea (adopt IMF aid). }\end{array}$ & Annual & $1980-2014$ \\
\hline PRED & $\begin{array}{l}\text { Previous } \\
\text { Crisis } \\
\text { Dummy }\end{array}$ & $\begin{array}{l}\text { Findings of } \\
\text { Reinhart \& } \\
\text { Rogoff (2014) }\end{array}$ & $\begin{array}{l}\text { Ouyang \& Rajan (2014) mention that, } \\
\text { economies without previous banking or debt } \\
\text { crises tend to accumulate a higher degree of } \\
\text { external debt without negatively affecting } \\
\text { growth. " } 1 \text { " is assigned to the years of crisis } \\
\text { and "0" is assigned to the years without crisis. }\end{array}$ & Annual & $1980-2014$ \\
\hline
\end{tabular}

The initial step in performing the analysis for this study is to construct a GPI for South Korea and Malaysia. We accomplish this by invoking the following equation:

$$
G P I_{i t}=C O N_{i t}+H L_{t}+S C D_{i t}+S H S_{i t}-C C_{i t}-C D_{i t}-A I R_{i t}-N A T_{i t}-F D_{i t}+C I_{i t}
$$

Here, for country $i$ and time $t$,

- $G P I_{i t}=$ Genuine Progress Indicator;

- $C O N_{i t}=$ Weighted Personal Consumption;

- $H L_{i t}=$ Household labour;

- $S C D_{i t}=$ Service from consumer durables;

- $S H S_{i t}=$ Service from highways and streets;

- $C C_{i t}=$ Cost of crime;

- $C D_{i t}=$ Consumer Durables;

- $\quad \mathrm{AIR}_{\mathrm{it}}=$ Cost of air pollution;

- $N A T_{i t}=$ Natural resources depletion;

- $F D_{i t}=$ Change in foreign debt;

- $C I_{i t}=$ Change in net capital investment

The employed variables and methodology rely on seminal works by Talberth \& Bohara (2006) and Tran (2011). For brevity, detailed GPI calculations are furnished in supplementary appendices. Components of the GPI, data sources and how they are calculated are in accordance with Table 2.

Next, we analyse the data in a double-log equation as formulated in equation (2) below:

$$
\begin{gathered}
\operatorname{lnY} Y_{\text {it }}=\beta_{0}+\beta_{1} \operatorname{lnDEBT}_{\text {it }}+\beta_{2} \operatorname{lnOPEN}_{\text {it }}+\beta_{3} \operatorname{lnPFC}_{\text {it }}+\beta_{4} \operatorname{lnUNEMP~}_{\text {it }}+\beta_{5} \mathrm{CRID}_{\text {it }}+ \\
\beta_{6} \text { COND }_{\text {it }}+\beta_{7} \text { PRED }_{\text {it }}+u_{\text {it }}
\end{gathered}
$$

Here, for country $i$ and time $t$ (to simplify, natural logs are dropped),

- $Y_{i t}=\mathrm{GDP} / \mathrm{GPI}$;

- $D E B T_{i t}=$ External debt; 
- $O P E N_{i t}=$ Trade openness;

- $\quad P F C_{i t}=$ Fixed capital;

- $\quad U N E M P_{i t}=$ Unemployment rate;

- $\quad C R I D_{i t}=$ Crisis dummy;

- $C O N D_{i t}=$ Capital controls dummy;

- $\quad P R E D_{i t}=$ Previous crisis dummy;

- $u_{i t}=$ error term;

The model in equation (1) extends on works by Othman et al. (2014) and Talberth \& Bohara (2006), who both utilize the Solow Growth Model, which proposes that GDP is a function of the nation's stocks of capital $(\mathrm{K})$ and labour $(\mathrm{L})$ as well as other determinants $(\mathrm{O})$ and can be formulated as GDPt $=\mathrm{f}\left(\mathrm{K}_{\mathrm{t}}, \mathrm{L}_{\mathrm{t}}, \mathrm{O}_{\mathrm{t}}\right)$. As such, extending the experimentation of Talberth and Bohara (2006), we test additionally for Ot factors such as financial liberalization (proxied via FDI), exchange rate stability (REER), and inflation. We apply customary econometric tests (Breusch-Pagan LM, Im-Pesaran-Shin Unit Root, and other Diagnostics) commensurate with standard panel data analysis.

Table 2. Summary of Data Sources (II).

\begin{tabular}{|c|c|c|c|c|c|}
\hline Code & Variable & Source & Details & Freq & $\begin{array}{l}\text { Period } \\
\text { available }\end{array}$ \\
\hline $\begin{array}{l}\mathrm{HCON} \\
\text { (\$bill) }\end{array}$ & $\begin{array}{l}\text { Household final } \\
\text { consumption ex- } \\
\text { penditure (bil- } \\
\text { lions of US\$) }\end{array}$ & World Bank & $\begin{array}{l}\text { Household final consumption ex- } \\
\text { penditure (current US\$) }\end{array}$ & Annual & $1980-2014$ \\
\hline DI & $\begin{array}{l}\text { Distribution In- } \\
\text { dex }\end{array}$ & $\begin{array}{l}\text { KOR: Kang (2001) } \\
\text { MYS: Official Web- } \\
\text { site of Economic } \\
\text { Planning Unit - } \\
\text { Household Income \& } \\
\text { Poverty }\end{array}$ & $\begin{array}{l}\text { Lowest Gini coefficient is set as } \\
\text { base (2014) and index is calculated } \\
\text { by finding difference between cur- } \\
\text { rent year and base year figure. Un- } \\
\text { available input follows the preced- } \\
\text { ing year input }\end{array}$ & Annual & $\begin{array}{l}\text { KOR: 1980- } \\
\text { 2000, 2006- } \\
\text { 2014MYS: } \\
\text { 1979, 1984, } \\
\text { 1987, 1989, } \\
\text { 1992, 1995, } \\
\text { 1997, 1999, } \\
2002,2007 \text {, } \\
2009,2012, \\
2014\end{array}$ \\
\hline $\begin{array}{l}+\mathrm{CON} \\
(\$ \text { bill })\end{array}$ & $\begin{array}{l}\text { Weighted Per- } \\
\text { sonal Consump- } \\
\text { tion (billions of } \\
\text { US\$) }\end{array}$ & NIL & HCON (\$bill) divided by DI & Annual & 1980-2014 \\
\hline $\begin{array}{l}+\mathrm{HL} \\
\text { (\$bill) }\end{array}$ & \multicolumn{2}{|c|}{ Household labor (billions of US\$) } & $\begin{array}{l}\text { Multiplication of WH, MW and } \\
\text { NH }\end{array}$ & Annual & $\begin{array}{l}\text { KOR: 1988- } \\
\text { 2014; MYS: } \\
\text { 2012-2014 }\end{array}$ \\
\hline WH & $\begin{array}{l}\text { Annual Working } \\
\text { Hours }\end{array}$ & NIL & $\begin{array}{l}\text { Total weeks per year minus VW, } \\
\text { assuming } 52 \text { weeks per year. }\end{array}$ & Annual & 1980-2014 \\
\hline VW & Vacation Weeks & $\begin{array}{l}\text { Justlanded.com web- } \\
\text { site }\end{array}$ & $\begin{array}{l}\text { Number of vacation weeks per } \\
\text { year. }\end{array}$ & Annual & 1980-2014 \\
\hline MW & Minimum Wage & $\begin{array}{l}\text { KOR: Minimum } \\
\text { Wage Council Re- } \\
\text { public of Korea, } \\
\text { ECOS Economic Sta- } \\
\text { tistics System, Bank } \\
\text { of Korea; MYS: Min- } \\
\text { imum Wages Malay- } \\
\text { sia }\end{array}$ & $\begin{array}{l}\text { Hourly minimum wage. Unavaila- } \\
\text { ble data is estimated at average ra- } \\
\text { tio of available minimum wage to } \\
\text { GDP per capita (South Korea: } \\
24.14 \% \text { and Malaysia: } 26.40 \% \text { ). }\end{array}$ & Annual & $\begin{array}{l}\text { KOR: 1988- } \\
\text { 2014; MYS: } \\
\text { 2012-2014 }\end{array}$ \\
\hline $\mathrm{NH}$ & $\begin{array}{l}\text { Number of } \\
\text { Households }\end{array}$ & World Bank & $\begin{array}{l}\text { Population divided average person } \\
\text { per household. }\end{array}$ & Annual & 1980-2014 \\
\hline
\end{tabular}




\begin{tabular}{|c|c|c|c|c|c|}
\hline $\begin{array}{l}+\mathrm{SCD} \\
\text { (\$bill) }\end{array}$ & $\begin{array}{l}\text { Service from con- } \\
\text { sumer durables } \\
\text { (billions of US\$) }\end{array}$ & $\begin{array}{l}\text { KOR: ECOS Eco- } \\
\text { nomic Statistics Sys- } \\
\text { tem, Bank of Korea; } \\
\text { MYS: UNdata Report } \\
\text { Database }\end{array}$ & $\begin{array}{l}\text { Following Tran( 2011), inputs are } \\
\text { derived from adding previous ten } \\
\text { years of consumer durables to ar- } \\
\text { rive at stock of consumer durables, } \\
\text { then multiplying by } 0.1 \text { ( } 10 \%) \text {. } \\
\text { Stock of consumer durables for } \\
1980 \text { until } 1989 \text { is computed by } \\
\text { discounting at average } 10 \text { years ra- } \\
\text { tio of the stocks to household final } \\
\text { consumption expenditure of fol- } \\
\text { lowing years (KOR: } 6 \% \text {, MYS: } \\
15 \% \text { ) }\end{array}$ & Annual & $\begin{array}{l}\text { KOR: 1980- } \\
\text { 2014; MYS: } \\
\text { 1983, 2000- } \\
2013\end{array}$ \\
\hline $\begin{array}{l}+ \text { SHS } \\
\text { (\$bill) }\end{array}$ & $\begin{array}{l}\text { Service from } \\
\text { highways and } \\
\text { streets (billions of } \\
\text { US\$) }\end{array}$ & World Bank & $\begin{array}{l}\text { Adjusted savings: consumption of } \\
\text { fixed capital (current US\$)' times } \\
\text { the total of 'Deposit interest rate } \\
(\%) \text { ' and depreciation rate. Depre- } \\
\text { ciation is assumed at } 7.5 \% \text { (Tal- } \\
\text { berth (2007). }\end{array}$ & Annual & $1980-2014$ \\
\hline $\begin{array}{l}-\mathrm{CC} \\
\text { (\$bill) }\end{array}$ & $\begin{array}{l}\text { Cost of crime } \\
\text { (billions of US\$) }\end{array}$ & $\begin{array}{l}\text { United Nations Crime } \\
\text { Trends Surveys } \\
\text { (United Nations Of- } \\
\text { fice on Drugs and } \\
\text { Crime Database - } \\
\text { UNODC), Korean } \\
\text { National Police } \\
\text { Agency (KNPA), } \\
\text { Amin (2014), Keng } \\
\text { (2005) }\end{array}$ & $\begin{array}{l}\text { Number of recorded offences } \\
\text { times costs of crime. }\end{array}$ & Annual & $\begin{array}{l}\text { 1980-2000, } \\
\text { KOR: 2005- } \\
\text { 2014, MYS: } \\
\text { 2004, 2007- } \\
2013\end{array}$ \\
\hline $\begin{array}{l}-\mathrm{CD} \\
\text { (\$bill) }\end{array}$ & $\begin{array}{l}\text { Consumer Dura- } \\
\text { bles (billions of } \\
\text { US\$) }\end{array}$ & $\begin{array}{l}\text { KOR: ECOS Eco- } \\
\text { nomic Statistics Sys- } \\
\text { tem, Bank of Korea; } \\
\text { MYS: UNdata Report } \\
\text { Database }\end{array}$ & $\begin{array}{l}\text { For Malaysia, only 'Furnishings, } \\
\text { household equipment and routine } \\
\text { maintenance of the house' assumed } \\
\text { as durables. }\end{array}$ & Annual & $\begin{array}{l}\text { KOR: 1980- } \\
\text { 2014; MYS: } \\
\text { 1983, 2000- } \\
2013\end{array}$ \\
\hline $\begin{array}{l}\text { - AIR } \\
\text { (\$bill) }\end{array}$ & $\begin{array}{l}\text { Cost of air pollu- } \\
\text { tion (billions of } \\
\text { US\$) }\end{array}$ & $\begin{array}{l}\text { The Cost of Air Pol- } \\
\text { lution - Health Im- } \\
\text { pacts of Road } \\
\text { Transport (OECD) }\end{array}$ & $\begin{array}{l}\text { Unavailable data being estimated } \\
\text { at annual growth rate } 0.25 \% \text { and } \\
\text { the cost is as percentage of total of } \\
\text { final household consumption. }\end{array}$ & Annual & $\begin{array}{l}\text { KOR: 2005, } \\
2010\end{array}$ \\
\hline $\begin{array}{l}-\mathrm{NAT} \\
\text { (\$bill) }\end{array}$ & $\begin{array}{l}\text { Natural resources } \\
\text { depletion (bil- } \\
\text { lions of US\$) }\end{array}$ & World Bank & $\begin{array}{l}\text { Adjusted savings: natural re- } \\
\text { sources depletion ( } \% \text { of GNI)' } \\
\text { times 'GNI (current US\$)'. }\end{array}$ & Annual & $1980-2014$ \\
\hline $\begin{array}{l}-\mathrm{FD} \\
\text { (\$bill) }\end{array}$ & $\begin{array}{l}\text { Change in foreign } \\
\text { debt position } \\
\text { (billions of US\$) }\end{array}$ & $\begin{array}{l}\text { Collins and Park } \\
\text { (1989), OECD Exter- } \\
\text { nal Debt Statistics } \\
\text { (EDS; various edi- } \\
\text { tions), Sheng (2009), } \\
\text { Bank of Korea, } \\
\text { World Bank }\end{array}$ & $\begin{array}{l}\text { Difference between External debt } \\
\text { previous year and current year. }\end{array}$ & Annual & $1980-2014$ \\
\hline $\begin{array}{l}+\mathrm{CI} \\
(\$ \text { bill })\end{array}$ & $\begin{array}{l}\text { Change in net } \\
\text { capital invest- } \\
\text { ment (billions of } \\
\text { US\$) }\end{array}$ & World Bank & $\begin{array}{l}\text { Amount of new capital (change in } \\
\text { 'gross fixed capital formation' from } \\
\text { previous year) minus capital re- } \\
\text { quirement. capital requirement }= \\
\text { changes in labour force participa- } \\
\text { tion rate times previous year's } \\
\text { gross fixed capital formation. }\end{array}$ & Annual & 1980-2014 \\
\hline
\end{tabular}

\section{Results}

Comparing the calculated GPI results for Malaysia and South Korea, we arrive at the following GDP-GPI curves. This conforms to most findings in the literature; the performance when measured by GPI is not as high as the one that GDP portrays. 
Figure 1. GDP and GPI: 1980 - 2014.

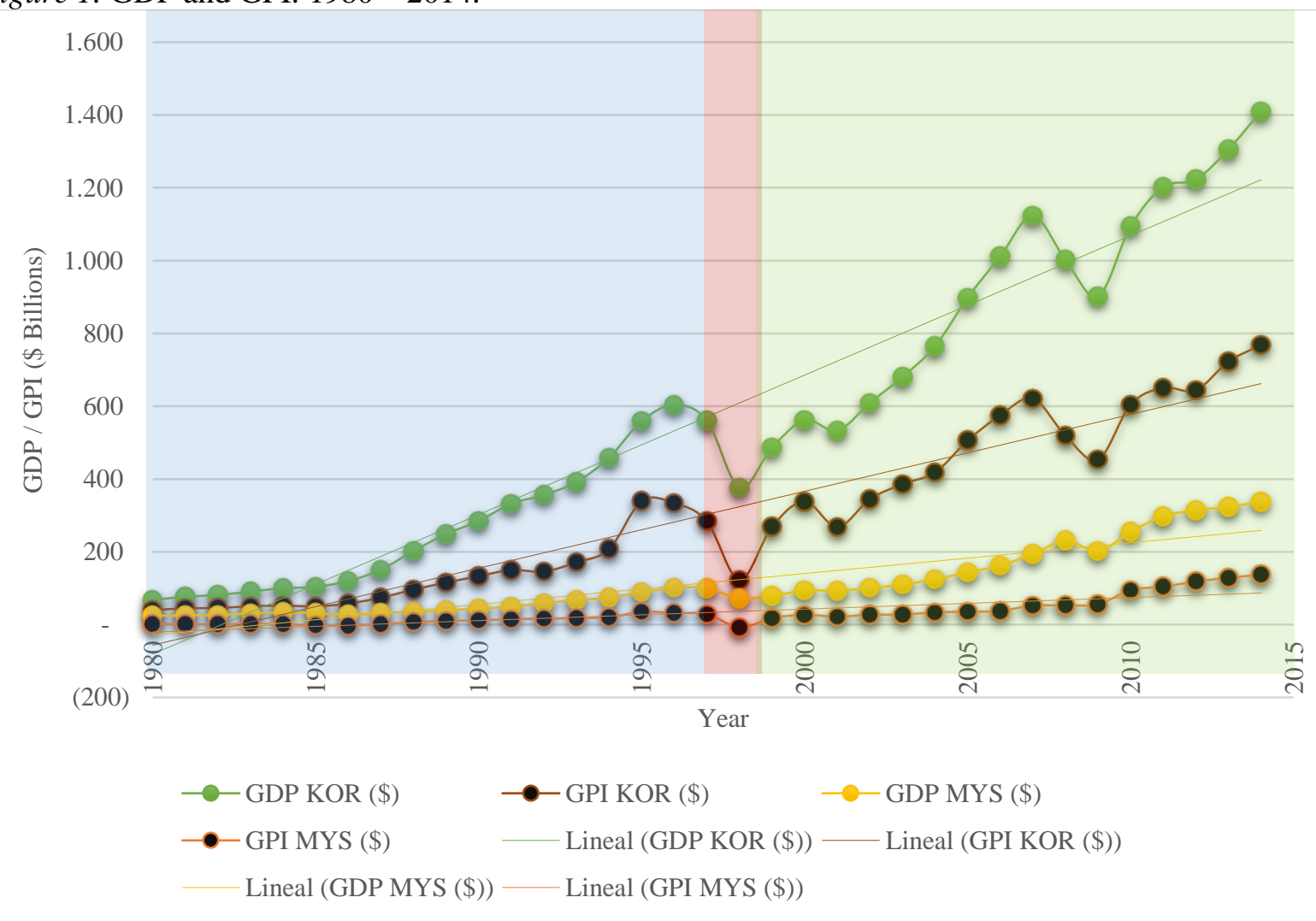

Note. Pre-crisis, crisis, and post-crisis periods are panellised in blue, red, and green shades.

Figure 2. GDP and GPI per capita: 1980 - 2014.

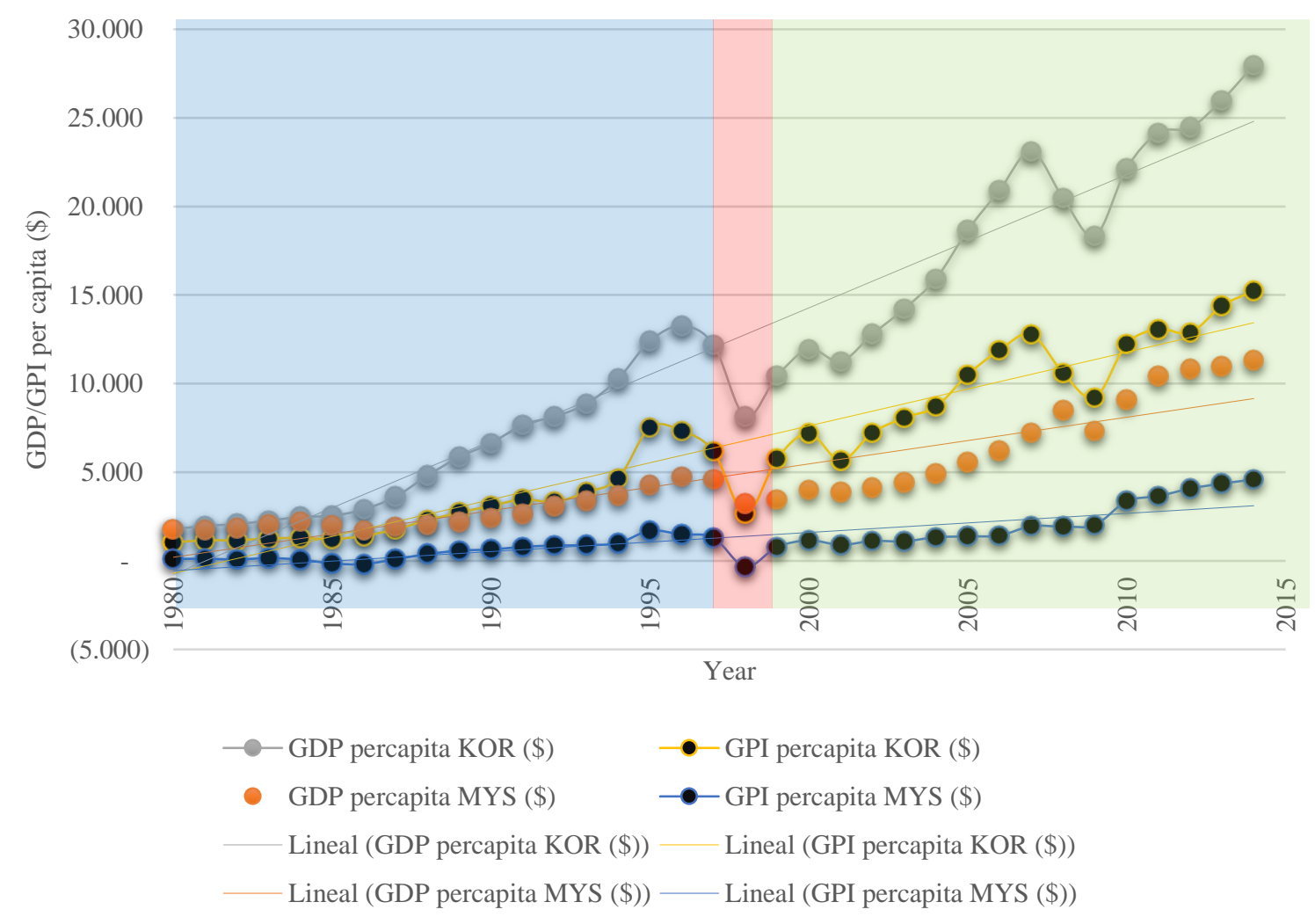

Note. Pre-crisis, crisis, and post-crisis periods are panellised in blue, red, and green shades. 
Figure 3. 30-year average components comparison to personal consumption expenditures.

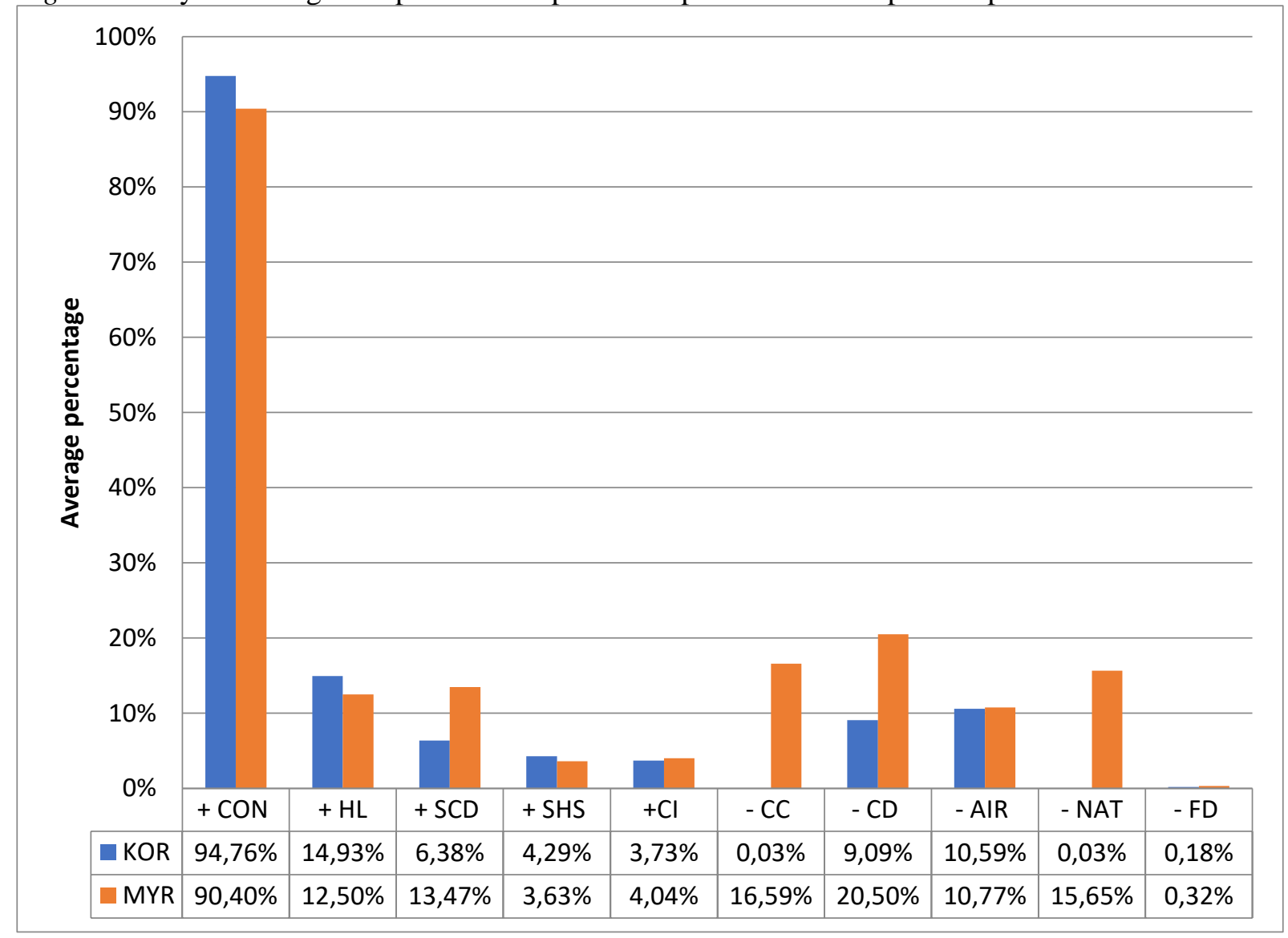

The divergence between the two indicators varies minimally between 1980 and 1986. Alarmingly, beyond 1986, per capita GPI fails to appreciate vis-a-vis per capita GDP. Besides, although both indicators grow positively, the difference in indicator growth exhibits a wedge between the two beyond 1986. South Korea's GDP and GPI per capita recede in 1998 and rise again after the Asian crisis. Both measures drop slightly in 2001 and continue to increase until 2007, yet maintaining the same gap. Around the subprime mortgage crisis, GPI per capita drops earlier in 2008 than the GDP per capita in 2009. Interestingly beyond 1986, the growth rate of both countries' GPI fails to match the pace in increase of respective per capita GDP. From this we surmise: firstly, the rise in GDP per capita underpins escalating social and environmental costs. Secondly, the speedy rise in per capita GDP overall does not translate to equivalency in sustainable welfare. The volatility and patterns in per capita GPI are inferior compared to rate of economic growth during the study time and can be explained by deconstructing the GPI compositions. On average, each component contributes to GPI differently. Compared to the personal consumption expenditures, almost $124 \%$ are additions from CON (92\%), HL (14\%), SCD (9\%), SHS (4\%), and CI (4\%) for both countries. However, deductions from MYS are greater than KOR approximately by $44 \%$; particularly on CC, CD and NAT by $17 \%, 11 \%$ and $16 \%$ respectively. 30 -year average components comparison to personal consumption expenditures for both countries is presented in Figure 3. The estimation results of panel data for all indicators, using OLS, Panel-Random, and Panel-Fixed effects, as well as three additional models are presented in Table 3.

The tables above demonstrate that changes in debt and unemployment are important determinants of GDP. Moreover, a direct and indirect relationship are observed between GDP against debt and unemployment respectively. Other influential determinants are trade openness, fixed capital level, trade openness, foreign direct investment, exchange rate, interest rates, and 
incidence of prior crisis. Financial crises and capital controls remain inconsequential. Tests with GPI as DV suggest debt and unemployment to be significant with $90 \%$ confidence per the fixed effects model Furthermore, debt and trade openness exhibit positive positive effect on GPI, while unemployment does the opposite. The largest magnitude increases on GPI at $1.025 \%$ per $1 \%$ rise comes from debt. All dummy variables show no significance. We summarize the results as follows (see Table 4).

Table 3. Panel data analysis with GDP (Panel A) and GPI (Panel B) as dependent variable; (1) Base model, (2) Fixed effects model, (3) Random effects model, (4) Robustness test 1, (5) Robustness test 2, and (6) Robustness test 3.

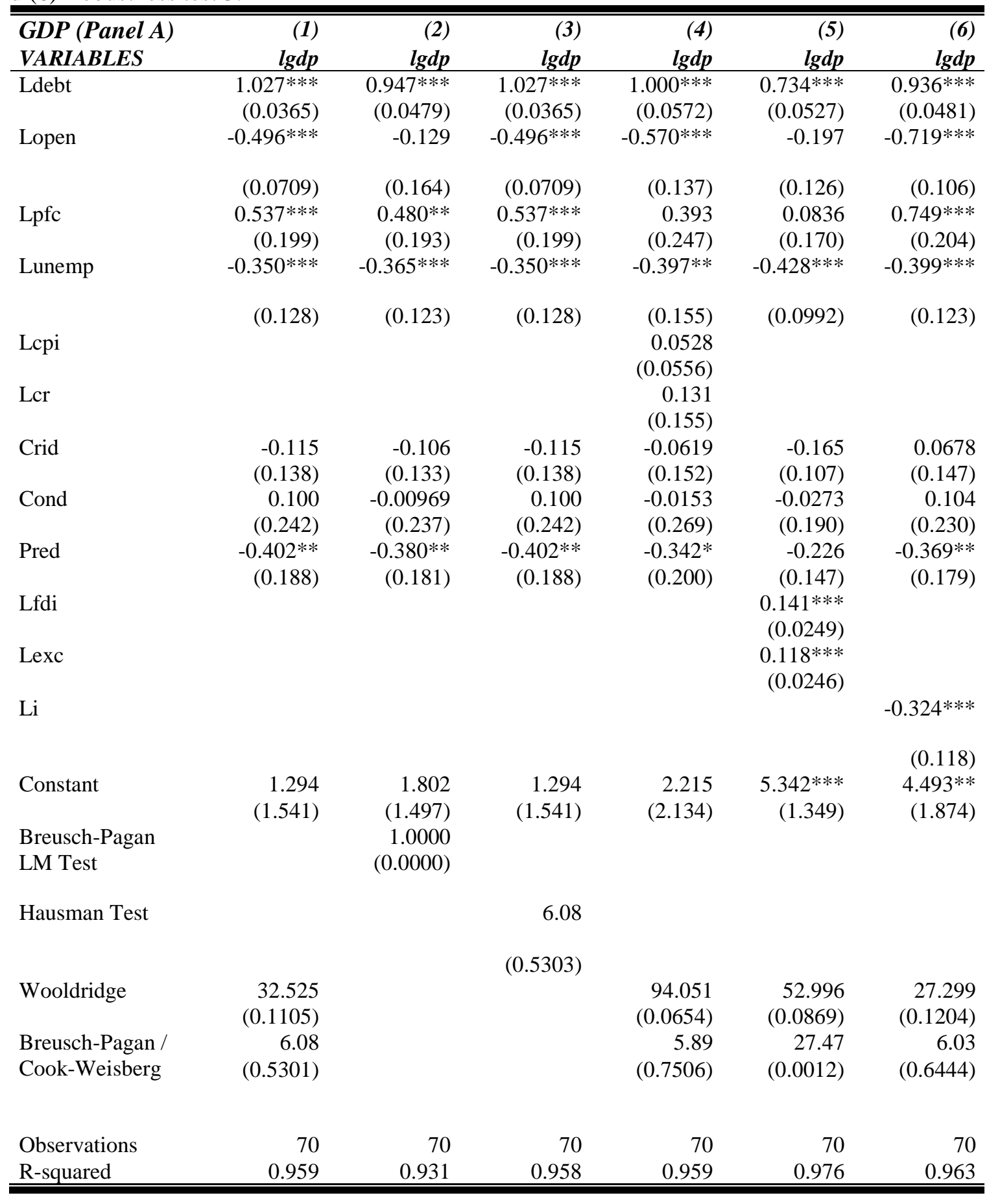


Table 3 (cont). Panel data analysis with GDP (Panel A) and GPI (Panel B) as dependent variable; (1) Base model, (2) Fixed effects model, (3) Random effects model, (4) Robustness test 1, (5) Robustness test 2, and (6) Robustness test 3.

\begin{tabular}{|c|c|c|c|c|c|c|}
\hline $\begin{array}{l}\text { GPI (Panel B) } \\
\text { VARIABLES } \\
\end{array}$ & $\begin{array}{r}(1) \\
\text { lgpi }\end{array}$ & $\begin{array}{r}(2) \\
\text { lgpi }\end{array}$ & $\begin{array}{r}(3) \\
\text { lgpi } \\
\end{array}$ & $\begin{array}{r}(4) \\
\text { lgpi } \\
\end{array}$ & $\begin{array}{r}(5) \\
\text { lgpi } \\
\end{array}$ & $\begin{array}{r}(6) \\
\text { lgpi } \\
\end{array}$ \\
\hline ldebt & $\begin{array}{r}1.380 * * * \\
(0.0854)\end{array}$ & $\begin{array}{r}1.025 * * * \\
(0.100)\end{array}$ & $\begin{array}{r}1.380 * * * \\
(0.0854)\end{array}$ & $\begin{array}{r}1.598 * * * \\
(0.132)\end{array}$ & $\begin{array}{r}0.859 * * * \\
(0.134)\end{array}$ & $\begin{array}{r}1.407 * * * \\
(0.121)\end{array}$ \\
\hline lopen & $\begin{array}{r}-0.916^{* * * *} \\
(0.167)\end{array}$ & $\begin{array}{l}0.692 * \\
(0.347)\end{array}$ & $\begin{array}{r}-0.916 * * * \\
(0.167)\end{array}$ & $\begin{array}{r}-0.344 \\
(0.315)\end{array}$ & $\begin{array}{l}0.574 * \\
(0.325)\end{array}$ & $\begin{array}{r}-0.848 * * * \\
(0.268)\end{array}$ \\
\hline lpfc & $\begin{array}{r}0.603 \\
(0.468)\end{array}$ & $\begin{array}{r}0.314 \\
(0.398)\end{array}$ & $\begin{array}{r}0.603 \\
(0.468)\end{array}$ & $\begin{array}{l}1.052 * \\
(0.562)\end{array}$ & $\begin{array}{r}0.121 \\
(0.428)\end{array}$ & $\begin{array}{r}0.543 \\
(0.507)\end{array}$ \\
\hline lunemp & $\begin{array}{r}-0.756 * * \\
(0.310)\end{array}$ & $\begin{array}{r}-0.927 * * * \\
(0.263)\end{array}$ & $\begin{array}{r}-0.756^{* *} \\
(0.310)\end{array}$ & $\begin{array}{r}-0.368 \\
(0.354)\end{array}$ & $\begin{array}{r}-1.012 * * * \\
(0.260)\end{array}$ & $\begin{array}{r}-0.737 * * \\
(0.318)\end{array}$ \\
\hline lcpi & & & & $\begin{array}{l}0.0567 \\
(0.131)\end{array}$ & & \\
\hline lcr & & & & $\begin{array}{l}-0.659^{*} \\
(0.354)\end{array}$ & & \\
\hline crid & $\begin{array}{r}-0.116 \\
(0.323)\end{array}$ & $\begin{array}{r}-0.0513 \\
(0.272)\end{array}$ & $\begin{array}{r}-0.116 \\
(0.323)\end{array}$ & $\begin{array}{r}-0.350 \\
(0.343)\end{array}$ & $\begin{array}{r}-0.120 \\
(0.267)\end{array}$ & $\begin{array}{l}-0.173 \\
(0.369)\end{array}$ \\
\hline cond & $\begin{array}{r}0.337 \\
(0.713)\end{array}$ & $\begin{array}{r}-0.229 \\
(0.610)\end{array}$ & $\begin{array}{r}0.337 \\
(0.713)\end{array}$ & $\begin{array}{r}0.704 \\
(0.738)\end{array}$ & $\begin{array}{r}-0.294 \\
(0.598)\end{array}$ & $\begin{array}{r}0.365 \\
(0.724)\end{array}$ \\
\hline pred & $\begin{array}{r}0.173 \\
(0.610)\end{array}$ & $\begin{array}{r}-0.147 \\
(0.516)\end{array}$ & $\begin{array}{r}0.173 \\
(0.610)\end{array}$ & $\begin{array}{l}0.0533 \\
(0.602)\end{array}$ & $\begin{array}{l}0.0205 \\
(0.516)\end{array}$ & $\begin{array}{r}0.176 \\
(0.615)\end{array}$ \\
\hline lfdi & & & & & $\begin{array}{r}0.0886 \\
(0.0631)\end{array}$ & \\
\hline lexc & & & & & $\begin{array}{r}0.352 * * * \\
(0.0642)\end{array}$ & \\
\hline li & & & & & & $\begin{array}{l}0.0976 \\
(0.301)\end{array}$ \\
\hline Constant & $\begin{array}{l}-6.370^{*} \\
(3.617)\end{array}$ & $\begin{array}{l}-3.761 \\
(3.082)\end{array}$ & $\begin{array}{r}-6.370 * \\
(3.617)\end{array}$ & $\begin{array}{r}-13.55 * * * \\
(4.886)\end{array}$ & $\begin{array}{r}-1.652 \\
(3.392)\end{array}$ & $\begin{array}{l}-7.359 \\
(4.752)\end{array}$ \\
\hline $\begin{array}{l}\text { Breusch-Pagan LM } \\
\text { Test }\end{array}$ & & $\begin{array}{r}1.0000 \\
(0.0000)\end{array}$ & & & & \\
\hline Hausman Test & & & $\begin{array}{r}26.90 \\
.0003) * * *\end{array}$ & & & \\
\hline Wooldridge & $\begin{array}{r}39.480 \\
(0.1005)\end{array}$ & & & $\begin{array}{r}33.266 \\
(0.1093)\end{array}$ & $\begin{array}{r}9.493 \\
(0.1998)\end{array}$ & $\begin{array}{r}108.441 \\
(0.0609)\end{array}$ \\
\hline $\begin{array}{l}\text { Breusch-Pagan / } \\
\text { Cook-Weisberg }\end{array}$ & $\begin{array}{r}36.97 \\
(0.0000)\end{array}$ & & & $\begin{array}{r}43.12 \\
(0.0000)\end{array}$ & $\begin{array}{r}40.93 \\
(0.0000)\end{array}$ & $\begin{array}{r}36.60 \\
(0.0000)\end{array}$ \\
\hline Observations & 67 & 67 & 67 & 67 & 67 & 67 \\
\hline R-squared & 0.893 & 0.848 & 0.898 & 0.902 & 0.930 & 0.893 \\
\hline
\end{tabular}

\section{Conclusion}

In this paper, we construct GPI for South Korea and Malaysia from 1980 to 2014. Notwithstanding a few omissions in GPI components owing to data unavailability, we find GPI curves to be lower than their GDP counterparts. Our panel estimations reveal that external debt has a direct relationship to both GDP and GPI in the long term. However, capital controls are insignificant to both GDP and GPI measures. The results also suggest that unemployment rate, trade openness, fixed capital formation and history of previous crises are influential drivers of GDP and GPI. Credit and exchange rates, however, show inconsistent effects in GDP and GPI. Further explanation is by answering the three following questions.

First: What are the determinants/variables that contribute to GPI? The determinants of GPI are different from GDP even though both begin from personal consumption. Several adjustments are made to GPI to reflect the sustainability element of the country's performance. These adjustments are not subject to a specific standard framework to be applied to all countries. 
For instance, consumer durables data for South Korea is available but not for Malaysia. Future researchers may exclude the variable or include it with a certain level of assumptions involved. However, for comparison purposes, we include the variable and make assumptions to ease the process - consistent with prior empirical praxis.

Even though variables included in computation of GPI are different from GDP, they unfurl crucial information uncaptured by GDP; e.g.: value of household works, costs of crimes, costs of natural resource depletions, and distribution index. These variables show different trends not parallel to the personal consumption trend. Comparing regressions for GDP and GPI together for explanation, we acknowledge the potency of each index in providing different points of view in defining growth: GDP as a comparable economic growth measure between nations due to standardized and worldwide usage, with GPI as a measure for sustainability performance.

The second and third questions will be explained together. Second: Does the use of external debt for crisis recovery boost a country's long-term growth (GDP and GPI)? Third: Does imposing capital controls for crisis recovery boost a country's long-term growth (GDP and GPI)? Regression outcomes suggest that external debt implementation contributes significantly to growth as indicated by both measures. In addition, the magnitude of debt-growth consistently shows higher positive values compared to other independent variables in all tests. Contrarily, capital controls dummy is insignificant regarding effect on growth of both GDP and GPI. Therefore, over a 35-year long window, external debt contributes positively to growth performance measured by either approach. Per contra, capital control imposition does not contribute to growth - in both approaches.

Lastly, we acknowledge inadequacy of evidence to draw conclusions about the contributions of these two policies in the short run. Given that there is literature that supports a temporary effect of capital controls on growth, the role of capital control in the short run cannot be ignored. These findings should enable policymakers to chart a different strategy for handling future crises from economic, well-being and sustainable viewpoints. This rings especially true for the emerging and crisis-prone economies, magnified further by percolation of interdependence and contagion in global economic climate.

Table 4. Consolidated findings.

\begin{tabular}{|c|c|c|c|c|c|c|}
\hline Variables & & Hypothesis & $\begin{array}{l}\text { GDP } \\
\text { Significance }\end{array}$ & Relationship & $\begin{array}{l}\text { GPI } \\
\text { Significance }\end{array}$ & Relationship \\
\hline ldebt & External debt & $+/-$ & YES & + & YES & + \\
\hline lopen & Trade openness & $+/-$ & YES & - & YES & $+/-$ \\
\hline lpfc & Fixed capital & + & YES & + & YES & + \\
\hline lunemp & Unemployment rate & - & YES & - & YES & - \\
\hline lcpi & Inflation & $+/-$ & NO & + & NO & + \\
\hline lcr & Credit & + & NO & + & YES & - \\
\hline crid & Asian crisis dummy & - & NO & - & NO & - \\
\hline cond & Capital controls dummy & + & NO & $+/-$ & NO & $+/-$ \\
\hline pred & Previous crisis dummy & - & YES & - & NO & - \\
\hline lfdi & Foreign direct investment & + & YES & + & NO & + \\
\hline lexc & Exchange rate & & YES & + & YES & + \\
\hline li & Interest rate & - & YES & - & NO & + \\
\hline
\end{tabular}

\section{References}

Bleys, B., and Whitby, A. (2015) Barriers and opportunities for alternative measures of economic welfare, Ecological Economics, 117, 162-172. 
Feeny, S., Mitchell, H., Tran, C., and Clarke, M. (2013) The determinants of economic growth versus genuine progress in South Korea, Social Indicators Research, 113(3), 1055-1074.

Othman, J., Jafari, Y., and Sarmidi, T. (2014) Economic growth, foreign direct investment, macroeconomic conditions and sustainability in Malaysia, Applied Econometrics and International Development, 14(1), 215-226.

Posner, S. M., and Costanza, R. (2011) A summary of ISEW and GPI studies at multiple scales and new estimates for Baltimore City, Baltimore County, and the State of Maryland, Ecological Economics, 70(11), 1972-1980.

Talberth, J., and Bohara, A. K. (2006) Economic openness and green GDP, Ecological Economics, 58(4), 743-758.

Talberth, J., Cobb, C., and Slattery, N. (2007) The Genuine Progress Indicator 2006: A Tool for Sustainable Development, Redefining Progress, (510), 1-31.

Zumkehr, H. J., and Andriesse, E. (2008) Malaysia and South Korea: A decade after the Asian financial crisis, Chulalongkorn Journal of Economics, 20(1), 1-26. 